\title{
PATOKAN HARGA NILAI JUAL OBJEK PAJAK (NJOP) DI KOTA BANDA ACEH: ANALISIS PERSPEKTIF MEKANISME HARGA DALAM ISLAM
}

\author{
Nilam Sari, Ridha Jadidah \\ FEBI UIN Ar-Raniry, nilam.sari@ar-raniriy.ac.id \\ FEBI UIN Ar-Raniry, ridha.jadidah@ar-raniry.ac.id
}

\begin{abstract}
Sale Value of Taxable Object (SVTO) is the averageprice obtained from the sale and purchase transactions that occur naturally, and when there is no buying or selling, then SVTO determined through a price comparison with other similar objects or substitution Although in operation, SVTO was not used directly in the case of land purchase, but sometimes the processes and mechanisms involved may violate the concept of buying and selling in Islam, such as the element of coercion and fair price. The researcher was intended to examine on how the processes and mechanisms of release of land by the government of Banda Aceh and how calculations of SVTO to the land purchase and its suitability with the Islamic price mechanism, the researcher conducted interviews with staff of UPTD PBB DPKAD of Banda Aceh. The descriptive analysis method was used in this, and the collecting data were analyzed qualitatively. The results showed that in the process and mechanism of release of land, the government does not use SVTO which is based on existing provisions. However, its implementation was done by estimating the real price of the object purchased. Not only that, but also it also referred to other possibilities such as land location. In general, the implementation is legal. The author suggests government to put more emphasis on adequate compensation to the community so that it can cover the costs of looking for a house/new land, the cost of moving, survival, and so on.
\end{abstract}

Keywords: Price determinitation, Sale Value of Taxable Object, Banda Aceh, Islamic Prices Mechanism 


\begin{abstract}
Abstrak
Nilai Jual Objek Pajak (NJOP) merupakan harga rata-rata yang diperoleh dari transaksi jual beli yang terjadi secara wajar, dan bilamana tidak terdapat transaksi jual beli, maka NJOP ditentukan melalui perbandingan harga dengan objek lain yang sejenis atau NJOP pengganti. Walaupun dalam operasionalnya, NJOP tidak digunakan secara langsung dalam kasus pembelian tanah, namun terkadang proses dan mekanisme yang terjadi bisa saja melanggar konsep jual beli dalam Islam, seperti unsur paksaan dan harga yang tidak layak.Peneliti ingin mengkaji bagaimana proses dan mekanisme pelepasan tanah oleh Pemerintah Kota Banda Aceh dan bagaimana perhitungan NJOP terhadap pembelian tanah tersebut serta kesesuaiannya dengan mekanisme harga dalam Islam. Untuk itu penulis melakukan wawancara dengan staf UPTD PBB DPKAD kota Banda Aceh. Penulisan tesis ini menggunakan metode deskriptif analisis, dan hasil data yang diperoleh di analisis secara kualitatif berdasarkan konsep-konsep penelitian. Hasil penelitian menunjukkan bahwa dalam melakukan proses dan mekanisme pelepasan tanah, pemerintah tidak menggunakan NJOP yang berdasarkan ketentuan yang ada. Namun implementasinya dengan melakukan taksiran harga riil terhadap material dari objek yang akan dibeli. Secara umum, penerapan implementasi tersebut sudah sesuai hukum. Namun penulis menyarankan agar pihak pemerintah lebih menekankan ganti rugi yang layak kepada masyarakat sehingga bisa menutupi biaya mencari rumah/lahan baru, biaya pindah, kelangsungan hidup dan sebagainya.
\end{abstract}

Kata Kunci: Patokan, Harga Nilai Jual Objek Pajak, Banda Aceh, Mekanisme Harga Islami 


\section{PENDAHULUAN}

Pemerintah kota dalam hal memajukan dan mengembangkan infrastruktur daerah melakukan pembangunan seperti pelebaran jalan, pembangunan perumahan, dan lain sebagainya tentu membutuhkan tanah dalam skala besar untuk memenuhi kebutuhan pembangunan dimaksud. Namun tanah-tanah yang dimiliki negara sangat terbatas, ataupun jika ada, lokasi tanah tersebut tidak pada wilayah yang diinginkan. Sehingga Pemerintah Kota menempuh jalan dengan pembebasan lahan/tanah yang dimiliki oleh rakyat (Mendagri, 1975) yang sering cendrung memaksa, karena jika pemilik tanah tidak mau menjual tanahnya, maka pemerintah akan menempuh jalur hukum dan pemilik tanah akan berhadapan langsung dengan pengadilan.

Dalam Pasal 18 Undang-Undang Pokok Agraria (UUPA) Tahun 1960 yang menyatakan bahwa:

Untuk kepentingan umum, termasuk kepentingan bangsa dan negara serta kepentingan bersama dari rakyat, hak-hak tanah dapat dicabut dengan memberi ganti kerugian yang layak dan menurut cara yang diatur dengan undang-udang.

Proses pencabutan paksa terhadap hak milik tanah ini tetap dilakukan, meski pemegang hak atas tanah tidak menerima keputusan besarnya ganti kerugian. Meskipun pemegang hak atas tanah dapat mengajukan banding ke pengadilan tinggi (Presiden, 1993). Tetapi putusan pengadilan tinggi merupakan putusan yang terakhir dan final sehingga tidak dapat lagi diajukan kasasi (Supriadi, 2012)

Ganti kerugian biasanya dilakukan dengan melakukan musyawarah antara pemerintah dengan pemilik tanah yang memungkinkan terjadiya perdebatanterkait jumlah ganti kerugian dan bentuk ganti rugi. Contoh kasus, pemerintah daerah dalam memberikan ganti kerugian di area Kapal Apung desa Punge Blang Cut,melaluimusyawarah dan 'janji-janji' bahwa ganti rugi akan diberikan dalam bentuk uang sebesar Rp 650.000/meter beserta satu unit rumah.Namun realisasinya, ganti rugi yang diberikan hanya dalam bentuk uang sebesarRp 450.000/meter tanpa rumah. Hal ini membuat masyarakat 'melarat' hidupnya setelah pelepasan paksa, dimana ada masyarakat pemilik tanah terpaksa tinggal di sekolah dan bekerja sebagai penjaga dan Cleaning Service sekolah tersebut.

Pemberian jumlah ganti rugi yang tidak layak juga pernah di alami oleh masyarakat pemilik lahan di simpang Jambo Tape. Salah satu masyarkat mengajukan keberatan kepada Pengadilan Negeri Banda Aceh terkait jumlah ganti rugi yang diberikan oleh pemerintah daerah. Namun nota keberatan tersebut tidak di gubris, jumlah ganti kerugian dipaksa harus diterima oleh masyarakat, melalui cara penitipan jum- 
lah ganti rugi kepada Pengadilan oleh Pemerintah Kota. Mencermati kedua kasus ini, dapat dipahami bahwa jika masyarakat yang ingin membela haknya tidak dapat lagi mempercayai Pengadilan, maka masyarakat harus bersandar pada dasar apa? Sedangkan Undang-undang sudah jelas menyebutkan bahwa jika tidak bersedia dengan jumlah ganti rugi maka dapat meminta banding di Pengadilan Tinggi (Presiden, 1993).

Dalam sejarah Islam, memang jual beli paksa juga pernah dilakukan pada masa pemerintahan khulafaurrasyidin seperti Umar bin Khattab dan Usman bin Affan guna memperluas ka'bah. Rumah-rumah dan lahan yang digusur berada disekitar Masjidil Haram, penggusuran dilakukan karena sudah semakin banyak kaum muslimin yang berziarah ke Mekkah. Hal ini dilakukan tidak terlepas dengan memberikan ganti kerugian kepada para pemilik rumah dan tanah (Tarmizi, 2013). Dalam konteks hari ini, pemerintah memberikan ganti rugi berdasarkan Nilai Jual Objek Pajak (NJOP) yang ditetapkan oleh Tim Penilai Harga Tanah (Presiden, 2005). NJOP ini juga ditetapkan dengan melihat acuan Pajak Bumi dan Bangunan (PBB) yang dibayarkan masyarakat yang terhimpun dari Pejabat Pembuat Akta Tanah (PPAT). Persoalan harga yang adil muncul ketika menghadapi harga yang sebenarnya, yaitu pembelian dan pertukaran barang. Ibnu Taimiyah menjelaskan bahwa harga yang adil atau setara adalah harga yang dibentuk oleh kekuatan permintaan dengan penawaran. Harga yang setara itu harus harga yang kompetitif pada pasar yang kompetitif pula, terlepas dari penipuan yang dapat menyebabkan kenaikan harga-harga (Karim, 2012).

Berdasarkan penjelasan di atas, maka penelitian ini bertujuan untuk melihat permasalahan terkait pembelian tanah oleh Pemerintah Kota dan keadilan harga dalam perhitungan nilai tanah yang sebenarnya agar tidak ada pihak yang dirugikan. Oleh karena itu,perlu kiranya dilakukan penelitian lebih lanjut.

\section{LANDASAN TEORETIS}

Setelah mengadakan kajian kepustakaan, penulis tidak menemukan pembahasan yang spesifik dan mendetail dalam tesis dan disertasi mengenai Analisis Perhitungan Nilai Riil Pembelian Tanah oleh Pemerintah Kota Banda Aceh terhadap Patokan harga NJOP. Namun ada beberapa tulisan yang berkaitan dengan penelitian ini, di antaranya:

Pertama, artikel tentang “Analisis Tingkat Akurasi Penetapan NJOP Tanah Terhadap Nilai Pasar dengan Metode Assessment Sales Ratio (Studi Kasus di Kecamatan Kelapa Gading Kota Madya Jakarta Utara)" (Novie \& Sandra, 2012). Penelitian ini membahas tentang assessment sales ratio yang digunakan untuk penetapan pajak suatu properti. Hasil penelitian ini menunjukkan bahwa NJOP di Kecamatan Kelapa Gading Jakarta Utara telah ditetapkan pada tingkat penilaian yang sama pada setiap 
kelurahannya, serta assessment ratio yang diterapkan sudah sesuai dengan standar IAAO.

Kedua, tesis yang disusun oleh Sonny Djoko Marlidjanto pada tahun 2010 tentang “Konsinyasi Ganti Rugi dalam Pengadaan Tanah untuk Kepentingan Umum (Studi Pengadaan Tanah untuk Pembangunan Proyek Jalan TOL Semarang-Solo di Kabupaten Semarang)" (Marlidjanto, 2010). Penelitian ini bertujuanuntuk mengetahui proses pengadaan tanah untuk kepentingan umum, hambatan-hambatan yang timbul danpengaruh terhadap pemilik tanah yang terkena proyek pembangunan Jalan ToL Semarang-Solo tersebut.

Ketiga, tesis yang disusun oleh Amgasussari Anugrahni Sangalangtahun 2012berjudul "Kajian terhadap Ganti Rugi atas Tanah dalam Pengadaan Tanah bagi Pembangunan untuk Kepentingan Umum Guna Mewujudkan Kepastian Hukum, Perlindungan Hukum, dan keadilan Berdasarkan Peraturan Presiden Nomor 36 Tahun 2005 dan Peraturan Presiden Nomor 65 Tahun 2006" (Sangalang, 2012). Tujuan penelitian ini untuk mengetahui apakah ganti rugi atas tanah berdasarkan Peraturan PresidenNomor 65 Tahun 2006 tersebut telah mewujudkan kepastian hukum, perlindungan hukum, dan keadilan bagi pemegang hak atas tanah.

Keempat, tesis yang disusun oleh Sugiarto pada tahun 2010 berjudul "Problematika Hukum dalam Pemberian Ganti Rugi terhadap Pengadaan Tanah bagi Pengembangan Landas Pacu Bandar Udara Ahmad Yani Semarang" (Sugiarto, 2010) . Tujuan penelitian ini untuk mengetahui bagaimana mekanisme dan upaya hukum dalam mengatasi kendala-kendala pemberian ganti rugi terhadap pengadaan tanah bagi pengembangan Landasan Pacu Bandara Ahmad Yani Semarang yang dilakukan Pemerintah Kota Semarang.

Kelima, jurnal yang disusun oleh Roy Frike Lasut pada tahun 2013tentang “Pelaksanaan Bentuk Ganti Rugi atas Tanah Menurut Undang-undang Nomor 2 Tahun 2012 tentang Pengadaan Tanah bagi Pembangunan untuk Kepentingan Umum". Tujuan penelitian ini untuk mengetahui bagaimana pelaksanaan ganti rugi atas kepemilikan tanah untuk kepentingan pembangunan menurut Undang-undang tersebutdan bagaimana mekanisme penyelesaian hukum ketika pemilik hak atas tanah menolak bentuk dan/atau besarnya ganti kerugian yang telah di tetapkan (Lasut, 2013).

Berdasarkan uraian diatas, maka penelitian yang penulis lakukan ini berbeda dengan penelitian-penelitian sebelumnya, baik dari segi analisis objek maupun metode penelitiannya. Sehingga penelitian tentang Analisis Perhitungan Nilai Riil Pembelian Tanah oleh Pemerintah Kota Banda Aceh terhadap Patokan NJOP perlu untuk dilakukan. 


\section{METODE}

\section{Jenis Penelitian}

Penelitian ini adalah penelitian lapangan (field research) dan penelitian kepustakaan (library research). Penelitian ini merupakan penelitian ekonomi Islam (muamalah). Penelitian ini membahas tentang prinsip-prinsip dan kejadian-kejadian yang terjadi dengan mengaitkan konsep ekonomi Islam.

\section{Pendekatan Penelitian}

Pendekatan yang digunakan dalam penelitian ini adalah pendekatan penelitian dengan metode kualitatif (Nazhir, 2005).

\section{Sumber Data}

Sumber data dalam pelitian ini dibagi menjadi dua kelompok, yaitu:

1. Sumber primer, yaitu bahan yang bersifat mengikat dan menjadi bahan utama dalam membahas suatu permasalahan. Sumber hukum primer dalam penelitian ini adalah informan yang terlibat dalam kegiatan penetapan harga NJOP.

2. Sumber sekunder, yaitu bahan pustaka yang berisi informasi tentang bahan hukum primer, seperti buku, jurnal, majalah, artikel, website dan hasil penelitian lainnya yang berkaitan dengan objek penelitian.

\section{Tekhnik Pengumpulan Data}

Teknik pengumpulan data merupakan prosedur yang sistematik dan standar untuk memperoleh data yang diperlukan (Nazhir, 2005). Dalam mengumpulkan data, di samping mempelajari dokumen-dokumen atau catatan-catatan yang mendukung penelitian ini, juga menggunakan metode pengumpulan data berikut:

a. Wawancara: berkomunikasi secara langsung dengan informan yang dianggap tepat dalam memberikan keterangan, yaitu Pengadilan Negeri Banda Aceh yaitu Bapak Disan selaku penanggung jawab terhadap kasus hukum, serta Balai Kota Banda Aceh yaitu Bapak Rizal Azwani selaku staf UPTD PBB DPKAD.

b. Observasi: mengamati hasil penelitian dan kasus-kasus yang sudah ada dan terbaru yang berkaitan dengan judul penelitian ini.

c. Dokumentasi: mengumpulkan buku-buku dan hasil penelitian yang berkaitan dengan Perhitungan Nilai Real pembelian Tanah oleh Pemerintah Kota Banda Aceh terhadap Patokan Harga NJOP.

Langkah-langkah kongkrit yang telah penulis lakukan dalam pengumpulan data adalah sebagai berikut:

a. Mencaridanmenemukan data-datayang berkaitan dengan pokokpermasalahan. 
b. Membaca dan meneliti data-data yang diperoleh untuk mendapatkan data yang lengkap dan valid.

c. Mencatat data secara sistematis dan konsisten.

\section{METODE ANALISIS DATA}

Metode analisis data yang digunakan dalam penelitian ini adalah deskriptif analisis, yaitu metode penelitian yang bertujuan mendeskripsikan atau menggambarkan secara objektif dan kritis dalam rangka memberikan perbaikan, tanggapan dan tawaran serta solusi terhadap permasalahan yang dihadapi sekarang (Nazhir, 2005). Dalam penelitian ini, setelah data-data yang telah diteliti dan dianalisis, selanjutnya ditarik kesimpulan tentang bagaimana Perhitungan Nilai Riil Pembelian Tanah oleh Pemerintah Kota Banda Aceh terhadap Patokan Harga NJOP.

\section{HASIL DAN PEMBAHASAN}

\section{Proses dan Mekanisme Pelepasan Tanah oleh Pemerintah Kota Banda Aceh}

Pembangunan ekonomi Indonesia harus dilaksanakan dengan mengikut sertakan peran masyarakat. Sebagaimana dalam Pasal 33 ayat (4) UUD 1945 yang berbunyi:

\section{"Perekonomian nasional diselenggarakan berdasar atas demokrasi ekonomi dengan prinsip kebersamaan, efisiensi berkeadilan, berkelanjutan, berwa- wasan lingkungan, kemandirian, serta dengan menjaga keseimbangan ke- majuan dan kesatuan ekonomi nasional"}

Masyarakat harus menyadari bahwa dana pemerintah terbatas, begitu pula daya untuk melaksanakan pembangunan ekonomi yang kompleks, sehingga diharapkan dapat tercipta saling mengisi antara pemerintah dengan masyarakat untuk keberhasilan pembangunan nasional (Manan, 2012). Khususnya dalam hal pelepasan tanah untuk kepentingan publik ini.

Pelepasan tanah dilakukan oleh Pemerintah Kota Banda Aceh tidak hanya berkaitan dengan kepentingan umum, melainkan juga pada pajak. Hal ini dilihat dari NJOP untuk menaksir biaya ganti rugi. Namun pajak memiliki dampak negatif pada konsumsi, meningkatnya pajak akan mengurangi pengeluaran konsumsi. Sehingga pengeluaran pajak akan meningkatkan pendapatan nasional dan sebaliknya (Huda, Idris, Nasution, \& Wiliasih, 2008).

Pemerintah Kota (Pemkot) dalam hal pembebasan hak atas tanah berdasarkan Undang-undang Nomor 2 Tahun 2012 tentang Pengadaan Tanah bagi Pembangunan dan Kepentingan Umum, serta Peraturan Presiden Nomor 71 Tahun 2012 tentang 
Penyelenggaraan Pengadaan Tanah Bagi Pembangunan untuk Kepentingan Umum (Perpres).

Mekanisme ganti rugi dimulai dari penilaian harga tanah oleh penilai publik dan penetapan lokasi di bawah pengawasan kantor BPN RI Kanwil Daerah. Berikut definisi yang pada dasarnya sama dengan Undang-Undang No.2 Tahun 2012. Namun dengan penambahan sebagai berikut:

1. Penilai Publik adalah penilai yang telah memperoleh izin dari Menteri Keuangan untuk memberikan jasa penilaian.

2. Penetapan Lokasi adalah penetapan atas lokasi pembangunan untuk kepentingan umum yang ditetapkan dengan keputusan Gubernur, yang dipergunakan sebagai izin untuk Pengadaan Tanah, perubahan penggunaan tanah, dan peralihan hak atas tanah dalam Pengadaan Tanah bagi pembangunan untuk kepentingan umum.

3. Badan Pertanahan Nasional Republik Indonesia yang selanjutnya disingkat BPN adalah Lembaga Pertanahan sebagaimana dimaksud dalam Undang-Undang Nomor 2 Tahun 2012 Tentang Pengadaan Tanah Bagi Pembangunan Untuk Kepentingan Umum.

4. Kantor Wilayah Badan Pertanahan Nasional Provinsi yang selanjutnya disebut Kantor Wilayah BPN adalah BPN di Provinsi yang dipimpin oleh Kepala Kantor Wilayah BPN yang berada di bawah dan bertanggung jawab langsung kepada Kepala BPN.

5. Kantor Pertanahan adalah BPN di Kabupaten/Kota yang dipimpin oleh Kepala Kantor Pertanahan yang berada di bawah dan bertanggung jawab kepada Kepala BPN melalui Kepala Kantor Wilayah BPN.

6. Tim Persiapan Pengadaan Tanah yang selanjutnya disebut Tim Persiapan adalah tim yang dibentuk oleh gubernur untuk membantu Gubernur dalam melaksanakan pemberitahuan rencana pembangunan, pendataan awal lokasi rencana pembangunan dan Konsultasi Publik rencana Pembangunan.

7. Tim Kajian Keberatan yang selanjutnya disebut sebagai Tim Kajian adalah tim yang dibentuk oleh gubernur untuk membantu Gubernur melaksanakan inventarisasi masalah yang menjadi alasan keberatan, melakukan pertemuan atau klarifikasi dengan pihak yang keberatan, membuat kajian dan membuat rekomendasi diterima atau ditolaknya keberatan.

8. Satuan Tugas adalah satuan yang dibentuk oleh BPN untuk membantu pelaksanaan Pengadaan Tanah.

9. Ruang atas tanah dan bawah tanah adalah ruang yang ada di bawah permukaan bumi dan/atau ruang yang ada di atas permukaan bumi sekedar diperlukan untuk kepentingan yang langsung berhubungan dengan penggunaan tanah. 
Selanjutnya, Penyelenggaraan Pengadaan Tanah Bagi Pembangunan untuk Kepentingan Umum ini memuat tahapan-tahapan dalam proses dan mekanismenya, yaitu tahapan perencanaan, persiapan, pelaksanaan dan penyerahan hasil (Az-Zuhaili, 2011).

\section{Perencanaan}

Sebelum tanah dibebaskan, terlebih dahulu melalui proses-proses perencanaan. Perencanaan pengadaan tanah ini berdasarkan atas:

a. Rencana Tata Ruang Wilayah

b. Rencana Pembangunan Jangka Menengah

c. Rencana Strategis, dan

d. Rencana Kerja Pemerintah Instansi yang bersangkutan

Semuanya ini disusun dalam bentuk: Dokumen Perencanaan Pengadaan Tanah, yang berisikan tentang:

a. Maksud dan tujuan rencana pembangunan

b. Kesesuaian dengan Rencana Tata Ruang Wilayah dan Rencana Pembangunan Nasional dan Daerah

c. Letak tanah

d. Luas tanah yang dibutuhkan

e. Gambaran umum status tanah

f. Perkiraan waktu pelaksanaan Pengadaan tanah

g. Perkiraan jangka waktu pelaksanaan pembangunan

h. Perkiraan nilai tanah, dan

i. Rencana penganggaran

Dokumen ini disusun berdasarkan studi kelayakan yang mencakup:

a. Survei sosial ekonomi

b. Kelayakan lokasi

c. Analisis biaya dan manfaat pembangunan bagi wilayah dan masyarakat

d. Perkiraan nilai tanah

e. Dampak lingkungan dan dampak sosial yang mungkin timbul akibat dari Pengadaan Tanah dan Pembangunan, serta

f. Studi lain yang diperlukan.

\section{Persiapan}

Dokumen perencanaan tersebut selanjutnya diberikan kepada Gubernur. Setelah Gubernur menerima Dokumen Perencanaan Pengadaan Tanah selanjutnya membentuk Tim Persiapan yang beranggotakan:

a. Bupati/Walikota 
b. Satuan kerja perangkat daerah provinsi terkait

c. Instansi yang memerlukan tanah, dan

d. Instansi terkait lainnya.

Dimana Tim Persiapan tersebut bertugas:

a. Mengumumkan rencana pembangunan

b. Melakukan pendataan awal lokasi rencana pembangunan

c. Melakukan Konsultasi Publik rencana pembangunan

d. Menyiapkan Penetapan Lokasi pembangunan

e. Mengumumkan Penetapan Lokasi pembangunan untuk kepentingan umum, dan

f. Melaksanakan tugas lain yang terkait persiapan Pengadaan Tanah bagi pembangunan untuk Kepentingan Umum, yang ditugaskan oleh Gubernur.

Selanjutnya, Tim Persiapan melakukan:

a. Pemberitahuan rencana pembangunan

Rencana pembangunan disampaikan kepada masyarakat pada rencana lokasi Pembangunan untuk Kepentingan Umum.

1) Langsung antara lain melalui sosialisasi, tatap muka, atau surat pemberitahuan.

2) Tidak Langsung antara lain melalui media cetak atau media elektronik.

b. Pendataan awal lokasi rencana pembangunan, meliputi kegiatan:

1) Pengumpulan data awal Pihak yang Berhak; dan

2) Objek Pengadaan Tanah.

Pihak yang berhak meliputi:

1) Perseorangan;

2) Badan hukum;

3) Badan sosial;

4) Badan keagamaan; atau

5) Instansi pemerintah.

Yang memiliki atau menguasai Objek Pengadaan Tanah sesuai dengan ketentuan peraturan perundang-undangan.

c. Konsultasi Publik Rencana Pembangunan

1) Dilaksanakan untuk mendapatkan kesepakatan lokasi rencana pembangunan dari Pihak yang Berhak.

2) Menghadirkan Pihak yang Berhak dan Masyarakat yang akan terkena dampak

3) Gubernur menetapkan lokasi dalam waktu paling lama 14 (empat belas) hari kerja terhitung sejak diterimanya permohonan Instansi. 


\section{Pelaksanaan}

Pelaksanaan Pengadaan Tanah meliputi:

a. Inventarisasi dan identifikasi penguasaan, pemilikan, penggunaan, dan pemanfaatan tanah

b. Penilaian Ganti Kerugian

c. Musyawarah penetapan Ganti Kerugian

d. Pemberian Ganti Kerugian, dan

e. Pelepasan tanah instansi

4. Penyerahan Hasil

Lembaga Pertanahan menyerahkan hasil Pengadaan Tanah kepada Instansi yang memerlukan tanah setelah:

a. Pemberian Ganti Kerugian kepada Pihak yang Berhak dan Pelepasan Hak; dan/atau

b. Pemberian Ganti Kerugian telah dititipkan di pengadilan negeri.

Secara lebih jelas, kegiatan Pelaksanaan Ganti Rugi pada Pembebasan Hak atas Tanah dapat dilihat dari segi:

1. Inventarisasi dan identifikasi penguasaan, pemilikan, penggunaan, dan pemanfaatan tanah

a. Meliputi kegiatan:

1) Pengukuran dan pemetaan bidang per bidang tanah, dan

2) Pengumpulan data Pihak yang Berhak dan Objek Pengadaan

b. Dilaksanakan dalam waktu paling lama 30 (tiga puluh hari) hari kerja.

c. Hasil inventarisasi dan identifikasi penguasaan, pemilikan, penggunaan, dan pemanfaatan tanah wajib diumumkan di kantor desa/kelurahan, kantor kecamatan, dan Tempat Pengadaan Tanah dilakukan dalam waktu paling lama 14 (empat belas) hari kerja.

d. Pengumuman hasil inventarisasi dan identifikasi meliputi subjek hak, luas, letak, dan peta bidang tanah Objek Pengadaan Tanah.

2. Pelaksanaan Ganti Kerugian meliputi:

a. Penilaian Ganti Kerugian dilakukan oleh Penilai yang ditetapkan oleh Lembaga Pertanahan

b. Penilaian dilakukan bidang per bidang tanah, meliputi:

1) tanah;

2) ruang atas tanah dan bawah tanah;

3) bangunan;

4) tanaman;

5) benda yang berkaitan dengan tanah; dan/atau

6) kerugian lain yang dapat dinilai. 
c. Pemberian Ganti Kerugian dapat diberikan dalam bentuk:

1) uang;

2) tanah pengganti;

3) permukiman kembali;

4) kepemilikan saham; atau

5) bentuk lain yang disetujui oleh kedua belah pihak.

Adapun sumber Pendanaan terhadap Ganti Rugi yang bersumber dari:

1. Anggaran Pendapatan dan Belanja Negara (APBN); dan/atau

2. Anggaran Pendapatan dan Belanja Daerah (APBD).

3. Badan Hukum Milik Negara/Badan Usaha Milik Negara yang mendapatkan penugasan khusus, pendanaan bersumber dari internal perusahaan atau sumber lain sesuai dengan ketentuan peraturan perundang-undangan.

Dana Pengadaan Tanah meliputi dana:

1. Perencanaan

2. Persiapan

3. Pelaksanaan

4. Penyerahan hasil

5. Administrasi dan pengelolaan, dan

6. Sosialisasi.

Berdasarkan uraian diatas, dapat dipahami bahwa pelaksanaan dilakukan melalui proses koordinasi internal yang berdasarkan dokumen yang ada. Selanjutnya dokumen tersebut dikirimkan ke Pemerintah Daerah untuk konsultasi publik. Jika masyarakat tidak setuju terhadap rencana ganti rugi tersebut, maka pemerintah akan melakukan kajian ulang. Apabila tidak ada tanah alternatif dan pengadaan tanah tetap harus dilaksanakan, maka dilakukan tuntutan yang diajukan ke Pengadilan Tata Usaha Negara (PTUN) mengenai SK Penetapan Lokasi tanah. Dalam hal ini masyarakat berhak untuk menolak terhadap pelepasan hak tanahnya melalui jalur hukum atau dengan cara yang diatur dalam undang-undang.

\section{Analisis Kesesuaian Perhitungan NJOP terhadap Pembelian Tanah oleh Pemerintah Kota Banda Aceh}

Baik pajak maupun pembelian tanah yang dilakukan oleh Pemerintah Kota Banda Aceh memiliki unsur paksaan kepada masyarakat. Secara fiqh, paksaan ini disebut dengan al-Ikraah. Yaitu perbuatan yang dilakukan oleh seseorang karena adanya paksaan dari orang lain, sedangkan ia tidak memiliki kemauan untuk melakukan hal tersebut (Az-Zuhaili, 2011) .

Paksaan yang dilakukan oleh pemerintah kota Banda Aceh termasuk kedalam 
al-Ikraah al-Adabi (paksaan yang bersifat pendisiplinan), yaitu paksaan tanpa adanya kerelaan dalam melakukan. Tetapi tidak sampai kepada ancaman dipenjara,hanya berkonsekuensi hukum bahwa hal yang dipaksakan harus dilakukan meski orang yang bersangkutan tidak rela melakukannya (Az-Zuhaili, 2011).

Pajak yang sesuai dengan norma-norma Islam adalah pajak yang dipungut dengan melihat kesanggupan masyarakat dalam membayar. Atau dengan kata lain cannons of taxation, sebagaimana yang diterangkan oleh Abu Yusuf. Tidak hanya kesanggupan dalam membayar, tetapi juga pemberian waktu dan sentralisasi pembuatan keputusan dalam administrasi pajak.

Agar pembayar pajak merasa diuntungkan dengan pajak, begitu pula terjaminnya pendapatan negara, maka pemerintah tidak boleh menetapkan pajak yang sama terhadap setiap objek pajak. Karena itu pemerintah harus meneliti secara mendalam terhadap nilai-nilai yang ada dari objek pajak tersebutdengan penilaian-penilaian yang cermat dan adil. Seperti layaknya tanah subur dan tanah tandus yang berbeda jumlah pajaknya. Al-Mawardi juga memikirkan hal yang demikian, tidak semua tanah sama pajak terutangnya, namun kualitas yang dihasilkan tanah tersebut juga harus dihitung. Begitu pula lokasi yang strategis seperti dekat dengan pusat perbelanjaan mempengaruhi tinggi rendahnya pajak terutang.

Pajak-pajak yang dijelaskan al-Syatibi dan Ibnu Khaldun juga demikian konsepnya. Namun Ibnu Khaldun lebih kepada konsep mikro-makro, dimana pajak tidak boleh terlalu tinggi atau terlalu rendah. Jika pajak terlalu rendah maka pemerintah tidak dapat menjalankan fungsinya dengan baik, sama halnya jika pajak terlalu tinggi maka ekonomi masyarakat menurun.

Masalah pajak ini berkaitan dengan pemberian ganti rugi. Jika ganti rugi diberikan terlalu rendah, maka masyarakat tidak dapat melanjutkan hidupnya dengan baik. Begitu pula jika ganti rugi diberikan terlalu tinggi maka pemerintah akan menurun fungsinya. Pajak dan ganti rugi ini tidak terlepas dari NJOP, karena laporan pajak masyarakat sebagai penentu NJOP dan ganti rugi berdasarkan NJOP.Perhitungan NJOP berdasarkan harga rata-rata yang diperoleh dari transaksi jual beli.

Perhitungan pembayaran setoran pajak kepada pemerintah Aceh bisa dikatakan sangat rendah, karena hanya 0,1\% (nol koma satu persen) tanpa penambahan perhitungan lainnya seperti perhitungan Nilai Jual Kena Pajak (NJKP) pusat yang sebesar 20\% (dua puluh persen) jika harta di bawah satu milyar, dan sebesar $40 \%$ (empat puluh persen) jika harta sebanyak satu milyar keatas (Presiden, 2000).

Karena Aceh memiliki Qanun sendiri mengenai tarif pajak sebagaimana disebutkan dalam Qanun Kota Banda Aceh Nomor 12 Tahun 2011 tentang Pajak Bumi dan 
Bangunan Pedesaan dan Perkotaan Pasal 6 yang berbunyi; "Tarif Pajak Bumi dan Bangunan Pedesaan dan Perkotaan ditetapkan sebesar 0,1\% (nol koma satu persen)”.

Di kota besar seperti Jakarta dan Medan, tarif PBB Pedesaan dan Perkotaan bisa mencapai 5-10\% (lima sampai sepuluh persen) dari objek pajak yang ada (Azwani, 2016). Karena itu tidak ada alasan bagi masyarakat untuk memanipulasi laporan pajak dengan alasan tarif pajak yang tinggi. Ketika pemerintah mencoba melakukan pembebasan lahan masyarakat dengan maksud untuk kepentingan umum, maka masyarakat akan menaikkan harga objek pelepasan lahan dengan harga yang melambung tinggi, bahkan berkali lipat dari harga NJOP dan harga riil material bangunan dan tanah.

Karena harga riil material dari bangunan dan tanah paling besar sejumlah $\mathrm{Rp}$ 800.000 (delapan ratus ribu rupiah) atau sampai Rp 1.250 .000 (satu juta dua ratus lima puluh ribu rupiah) saja per meternya (Azwani, 2016). Jadi tidak sampai Rp 2.000.000 (dua juta rupiah) atau Rp 3.000.000 (tiga juta rupiah) per meternya, atau bahkan lebih dari itu. Sehingga yang selama ini terjadi masyarakat melebih-lebihkan jumlah ganti rugi yang membuat pemerintah kewalahan dalam penerapan pelepasan lahan.

Ketika terjadi pelepasan lahan yang dilakukan pada sebuah komplek, maka perhitungan ganti rugi berbeda di setiap lapisan komplek. Seperti jika lapisan luar yang dekat dengan jalan besar atau jalan raya maka jumlah ganti rugi pasti lebih besar dari lapisan dalam, sehingga lapisan terdalam dengan nilai paling rendah (Azwani, 2016). Disamping itu, masyarakat juga memerlukan biaya relokasi dalam proses pelepasan lahannya. Karena penggusuran paksa bisa dilakukan dalam kurun waktu empat belas hari setelah musyawarah dilakukan oleh karena itu, pemerintah harus memperhitungkan hal-hal seperti ini dengan cermat.

Ganti rugi memang hal yang sensitif dan dapat menimbulkan konflik. Ganti kerugian yang diberikan dari pihak instansi yang memerlukan tanah haruslah yang layak. Namun, masyarakat juga tidak boleh jika berlaku tidak adil kepada pemerintah. Jangan sampai tidak pernah membayar PBB sekalipun, tetapi ingin ganti kerugian dalam jumlah yang layak.

Sebagaimana perhitungan ganti rugi yang didasarkan pada NJOPTKP (Nilai Jual Objek Pajak Tidak Kena Pajak) adalah batas NJOP terhadap bumi dan bangunan yang tidak kena pajak. Berdasarkan Pasal 77 ayat (4) besarnya NJOPTKP ditetapkan paling rendah sebesar Rp 10.000.000 (sepuluh juta) (Presiden, 2009). Pasal 80 ayat (1) juga menyebutkan bahwa untuk tarif pajak pada Pajak Bumi dan Bangunan di Perdesaan dan Perkotaan ditetapkan paling tinggi sebesar 0,3\% (nol koma tiga persen).

Selain itu terdapat pula NJKP (Nilai Jual Kena Pajak). NJKP adalah persentase 
NJOP terhadap bumi dan bangunan yang terkena pajak. Sebagaimana dalam PP No 46 Tahun 2000 tentang Penetapan Besarnya Nilai Jual Kena Pajak untuk Perhitungan Pajak Bumi dan Bangunan Pasal 1 menyebutkan bahwa objek pajak untuk perkebunan sebesar $40 \%$ dari NJOP, objek pajak kehutanan sebesar 40\% dari NJOP, objek pajak pertambangan sebesar 20\% dari NJOP, dan objek pajak lainnya sebesar $40 \%$ jika NJOP sebesar Rp 1.000.000.000 (satu milyar rupiah) atau lebih, serta objek pajak sebesar 20\% jika NJOP kurang dari Rp 1.000.000.000 (satu milyar rupiah).

Sebagai contoh: Bapak Muhammad memiliki objek pajak berupa:

- Tanah seluas $1000 \mathrm{~m}^{2}$ dengan nilai jual Rp 300.000/m²

- Bangunan seluas $550 \mathrm{~m}^{2}$ dengan nilai jual $\mathrm{Rp} 400.000 / \mathrm{m}^{2}$

- Pagar mewah sepanjang $1010 \mathrm{~m}$ dengan tinggi 1,5m dengan nilai jual $\mathrm{Rp}$ $200.000 / \mathrm{m}$.

Maka PBB dihitung secara terperinci sebagai berikut:

- NJ tanah $1000 \times \operatorname{Rp} 300.000 \quad=R p 300.000 .000$

- NJ rumah $550 \times \operatorname{Rp} 400.000 \quad=\operatorname{Rp} 220.000 .000$

- $\operatorname{Pagar}(1010 \times 1,5) \times R p 200.000=R p 303.000 .000+$

NJ rumah dan Pagar $\quad=$ Rp 523.000 .000

Batas NJOPTKP $\quad=\underline{\text { Rp } 10.000 .000-}$

NJKP bangunan $\quad=$ Rp 513.000 .000

Perhitungan pajaknya adalah sebagai berikut:

- $\quad$ PBB atas tanah (tarif pajak x NJKP x NJOP)

$0,3 \% \times 20 \% \times 300.000 .000=R p 180.000$

- $\quad$ PBB atas rumah dan pagar

$0,3 \% \times 20 \% \times \operatorname{Rp} 523.000 .000=\underline{\operatorname{Rp} 313.800+}$

PBB seluruhnya $\quad=R p 493.800$

Berbeda dengan perhitungan pada pemerintahan Aceh karena Aceh memiliki aturan sendiri mengenai NJOPTKP (Nilai Jual Objek Pajak Tidak Kena Pajak) dan tarif pajak. Semuanya diatur dalam Qanun Kota Banda Aceh.

Berdasarkan Pasal 6 ayat (4) besarnya NJOPTKP sebesar Rp 25.000.000 (dua puluh lima juta rupiah) untuk setiap wajib pajak (Walikota, 2011). Selanjutnya Pasal 7 juga menyebutkan bahwa untuk tarif pajak pada Pajak Bumi dan Bangunan di Perdesaan dan Perkotaan ditetapkan sebesar 0,1\% (nol koma satu persen) (Walikota, 2011).

Perhitungan pajak terutang jika sesuai NJOP Qanun Aceh adalah sebagai berikut; 
Bapak Bagas memiliki objek pajak berupa:

a. Tanah seluas $1000 \mathrm{~m}^{2}$ dengan nilai jual $\mathrm{Rp} 300.000 / \mathrm{m}^{2}$

b. Bangunan seluas $550 \mathrm{~m}^{2}$ dengan nilai jual $\mathrm{Rp} 400.000 / \mathrm{m}^{2}$

c. Pagar mewah sepanjang $1010 \mathrm{~m}$ dengan tinggi 1,5m dengan nilai jual $\mathrm{Rp}$ $200.000 / \mathrm{m}$.

Maka PBB dihitung secara terperinci sebagai berikut:
a. NJ tanah $1000 \times \mathrm{Rp} 300.000=\mathrm{Rp} 300.000 .000$
b. NJ rumah $550 \times \operatorname{Rp} 400.000=R p 220.000 .000$
c. Pagar $(1010 \times 1,5) \times R p 200.000=\underline{R p 303.000 .000+}$
NJ rumah dan Pagar $\quad=$ Rp 523.000 .000
Batas NJOPTKP $\quad=\underline{\text { Rp } 25.000 .000-}$
NJKP bangunan $\quad=$ Rp 498.000 .000

Perhitungan pajaknya adalah sebagai berikut:

PBB yang terutang

$0,1 \% \times 498.000 .000=R p 498.000$

Tentu hal ini belum termasuk jika Wajib Pajak memiliki objek lain seperti kolam renang, taman mewah, kolam ikan, dan sebagainya maka perhitungan pajaknya ditambahkan lagi dengan terperinci, tidak hanya bangunan rumah saja. Semua objek material dihitung dengan cermat dan tepat.

Sebagaimana yang tercantum dalam Undang-undang Pokok Agraria (UUPA) Pasal 18 yang berbunyi; “Untuk kepentingan umum, termasuk kepentingan bangsa dan Negara serta kepentingan bersama dari rakyat, hak-hak atas tanah dapat dicabut, dengan memberi ganti kerugian yang layak dan menurut cara yang diatur dengan Undang-undang".

Jika pemerintah tidak memperhitungkan hal yang demikian, maka masyarakat dapat melapor ke pihak berwajib atau membawa kasus ini ke pengadilan. Jika keputusan pengadilan merasa tidak puas, maka bisa melakukan banding kepada Pengadilan Tinggi sesuai dengan lanjutan penjelasan dalam Keppres Nomor 55 tahun 1993 Pasal 8 ayat (1). Namun demikian, putusan Pengadilan Tinggi tersebut merupakan putusan terakhir dan final serta tidak dapat lagi diajukan kasasi. Oleh Karena itu,pengadilan harus memutuskan dengan sebaik-baiknya agar tidak terjadi aniaya dalam proses ganti rugi tersebut.

Terbukti dengan adanya kasus di Pengadilan pada tahun 2013, seorang Pegawai Negeri Sipil yang beralamat di kampung Jawa, kecamatan Kuta Raja yang melakukan 
tuntutan kepada pemerintah kota Banda Aceh terhadap ganti rugi yang ia terima karena merasa kurang layak. Kasus ini ia menangkan dengan melakukan banding dan putusan Pengadilan di bacakan pada tahun 2015 (Negeri, 2013).

Karena itu masyarakat haruslah aktif dan sadar dalam melakukan pembayaran PBB, karena manfaatnya akan terlihat bagi masyarakat sendiri di masa mendatang. Tarif pajak yang kecil dengan jumlah NJOP yang kecil pula bukan untuk memberatkan masyarakat, tetapi untuk meringankan masyarakat sendiri dalam melakukan pembayaran pajak. Dan memudahkan pemerintah dalam menghitung nilai riil tanah dan bangunan ketika akan melakukan pembelian tanah.

\section{Analisis Kesesuaian NJOP dengan Mekanisme Harga dalam Islam}

Islam menjunjung tinggi hak pribadi, begitu pula hak pemerintah dalam menjalankan tugasnya untuk mengelola negara. Pembebasan tanah boleh dilakukan oleh pemerintah jika itu untuk kemashlahatan umat. Namun dalam proses terjadinya transaksi tidak boleh adanya aniaya, karena prinsip dasar jual beli yaitu sama-sama rela, sebagaimana hadist Nabi SAW:

Artinya: diriwayatkan dari Sa'id bin Zaid bin Amr bin Nufail ra, dia telah berkata: sesungguhnya Rasulullah SAW pernah bersabda: "barang siapa mengambil sejengkal tanah secara paksa (merampas), Allah akan mengalungkan tujuh lapis bumi di lehernya pada hari kiamat nanti." (HR. Muttafaqun 'Alaih). (Mahalli \& Hasbullah, 2004)

Dari hadis di atas terlihat jelas bahwa dalam pelepasan lahan yang dilakukan oleh sesama masyarakat dan pemerintah tidak boleh dengan merampas, karena ganjaran yang diberikan Allah SWT sangat besar. Namun, jika dilakukan untuk kepentingan umum(al-mashlahah al-ammah), maka haruslah dilakukan dengan norma-norma yang islami. Al-maslahah al-ammah adalah kebutuhan nyata bersifat lahiriah maupun batiniah bagi manusia dalam kawasan tertentu yang dapat menyejahterakan kehidupannya,terkait ketertiban dan keamanan dalam kehidupan manusia.

Undang-undang menyebutkan bahwa apabila proses pencabutan hak atas tanah telah dilakukan, tetapi pemilik tanah tidak mau menerima keputusan pencabutan hak tersebut, maka pemegang hak atas tanah berhak menolak dengan mengajukan banding ke pengadilan tinggi, hal ini sesuai dengan ketentuan Undang-Undang No.2 Tahun 2012 dalam Pasal 23 ayat (1) dan (3).Pengadilan akan memutuskan dengan sebaik-baiknya agar tidak terjadi aniaya dalam pelepasan hak untuk kepentingan umum ini. Di dalam Islam sendiri dijelaskan bahwa:

Artinya: diriwayatkan dari Ibn Abbas ra, dia telah berkata sesungguhnya

Nabi SAW telah bersabda: "sekiranya manusia diberi peluang untuk mel- 
akukan tuntutan, niscaya mereka akan membuat tuntutan darah dan harta.

(karena itu penunut mesti mendatangkan saksi). Tetapi, sumpah itu diwajibkan atas orang yang terdakwa." (HR. Muttafaqun 'Alaih)

Dalam memberikan ganti rugi, jelas terlihat dari pendapat Ibnu Thaimiyah mengenai 'iwadh al-mitsl ketika membahas kewajiban moral dan hukum. Seperti memberikan ganti kerugian. Dalam hal ini berarti pemerintah bertanggung jawab karena telah merusak harta orang lainatau masyarakat kehilangan hak miliknya karena pembelian paksa pemerintah. Oleh karena itu, pemerintah wajib untuk membayar kembali ganti rugi, setara dengan kehilangan yang di alami masyarakat sehingga mampu untuk relokasi dengan harga yang setara, yaitu harga yang dibentuk oleh kekuatan pasar antara permintaan dan penawaran.

Yahya bin Umar juga menjelaskan bahwa penetapan harga dalam sebuah transaksi semata-mata hasil interaksi penawaran dan permintaan yang alami. Sehingga pemerintah tidak boleh melakukan intervensi harga kecuali jika terjadi persaingan tidak sehat antar penjual. Mekanisme harga yang terjadi harus tunduk kepada kaidahkaidah Islam. Namun, sebagaimana pendapat Abu Ubaid, seorang penguasa yang adil dapat memperluas berbagai batasan apabila kepentingan publik sangat mendesak, seperti perluasan jalan, rumah sakit, tempat ibadah dan lainnya. Tetapi tidak keluar dari konteks harga yang islami dalam proses dan mekanismenya, seperti yang telah dijelaskan sebelumnya.

Islam mengatur bahwa ganti kerugian harus sesuai dengan harga yang berlaku. Rasulullah SAW pernah membeli tanah untuk dibangunnya mesjid di Madinah. Implementasi ganti rugi tidak menyebabkan mereka mengalami kerugian. Begitu pula terhadap penolakan harga ganti rugi tanah yang seharusnya terjadi musyawarah antara pemerintah yang membutuhkan tanah dengan masyarakat pemilik tanah, hal ini dilakukan demi terciptanya kesejahteraan sebagaimana yang menjadi dasar dalam Islam dan menjadi landasan dasar terciptanya UUPA.

Masyarakat tidak boleh menaikkan harga tanah di luar batas kewajaran untuk memperoleh keuntungan, karena pelepasan hak milik atas tanah yang dilakukan oleh pemerintah hanya untuk kepentingan umum. Oleh sebab itu konsep jual beli dalam Islam merupakan jual beli rela sama rela antara kedua belah pihak, yang dalam hal ini berarti instansi yang memerlukan tanah dengan masyarakat yang akan dibebaskan haknya.

Pembebasan lahan dalam wujud jual beli secara paksa memang dilarang. Namun, dalam kondisi tertentujual beli terpaksa ini dibolehkan syariat demi kemashlahatan umat. Pelepasan lahan dengan terpaksa ini juga pernah terjadi pada masa Umar bin Khattab dan Usman bin Affan yang melakukan perluasan pada Masjidil Har- 
am karena sudah sangat banyak muslim yang ingin melakukan haji.

Umar bin Khattab menggusur rumah-rumah yang berada di sekitar MasjidilHaramdan memberikan ganti kerugian kepada para pemilik rumah dan tanah. Ada beberapa orang yang menolak penggusuran tersebut, namun Umar tetap melakukan penggusuran paksa dan meletakkan uang ganti kerugian di dalam kakbah (Tarmizi, 2013). Kebijakan Umar ini dilanjutkan oleh Usman bin Affan, namun pada masanya melakukan penggusuran, pemilik rumah dan tanah menghalangi jalannya penggusuran, karena mengenal kebijakan Usman dan kesantunannya, namun tidak ada yang menghalangi ketika Umar bin Khattab yang melakukannya. Sehingga Usman memanggil mereka dan memenjarakan mereka selama beberapa hari. Kebijakan mereka yang tidak di tentang oleh para sahabat ini, bisa di anggap sebagai ijma (Tarmizi, 2013).

Jual beli paksa untuk kepentingan umum ini dibenarkan dan dikukuhkan oleh Majma' al-Fiqh al-Islami (divisi fikih OKI) dengan Nomor keputusan (29) 4/4 Tahun $1998 \mathrm{M}$, dan menambahkan beberapa persyaratan yang wajib diperhatikan saat hal itu dilakukan penggusuran. Adapun keputusan tersebut:

"Setelah menelaah penelitian-penelitian yang diajukan oleh para pakar fikih tentang hukum penggusuran secara paksa demi kepentingan umum yang membolehkan hal tersebut berdasarkan dalil dari hadis dan perbuatan para sahabat (khalifah Umar dan Usman) serta kebijakan para pemimpin selanjutnya... maka diputuskan:

Tidak boleh melakukan penggusuran paksa untuk kepentingan umum kecuali dengan memperhatikan hal-hal berikut:

a). Pemilik tanah dan rumah yang digusur paksa harus mendapat ganti rugi yang adil, ditentukan oleh pihak ketiga yang berpengalaman, dan harganya tidak boleh di bawah harga pasar serta dibayar sesegera mungkin.

b). Pihak yang menggusur hanyalah pemerintah setempat atau instansi yang ditunjuk oleh pemerintah.

c). Tujuan penggusuran untuk kepentingan umum yang sifatnya menyangkut kebutuhan mendesak untuk orang banyak, seperti; masjid, jalan dan jembatan.

d). Tujuan penggusuran bukan untuk investasi pemerintah atau pribadi. Jika salah satu persyaratan di atas dilanggar maka status penggusurannya termasuk kezaliman dan merampas hak rakyat yang dilarang oleh Allah dan Rasul-Nya."

Jika syarat yang disebutkan tadi hilang salah satunya maka termasuk kezaliman pemerintah kepada masyarakat, maka memanipulasi pajak juga merupakan kezaliman yang dilakukan masyarakat kepada pemerintah. Untuk itu sudah sepatutnya jika masyarakat dan pemerintah tidak saling menzalimi dengan cara pemerintah mem- 
berikan ganti rugi yang layak kepada masyarakat, dan masyarakat melakukan pembayarann PBB Perdesaan dan Perkotaan sebagaimana semestinya terhadap NJOP.

Fuqaha menetapkan empat keadaan dimana boleh dilakukannya pengambilalihan dan penyitaan kepemilikan, yaitu:

1. Pengambilalihan dan penyitaan terhadap suatu kepemilikan demi kemanfaatan dan kebaikan umum, seperti membuat jalan, pelebaran masjid, pelebaran kawasan pemakaman dan sebagainya, sementara tidak ada lahan lain yang bisa digunakan untuk hal tersebut.

2. Pemiliknya memiliki tanggungan utang, seperti tanggungan utang nafkah keluarga, tanggungan pajak bumi (kharaj), tanggungan utang karena suatu transaksi atau sebagainya. Dalam hal ini hakim boleh menyita dan menjual asetnya secara paksa untuk melunasi hutangnya itu.

3. Suatu kepemilikan diambil dan disita sebagai langkah pencegahan terhadap praktik monopoli. Contohnya pedagang yang melakukan penimbunan barang dan monopoli terhadap makanan pokok.

4. Kasus pengambilan hak syuf'ah (hak prioritas untuk membeli) oleh syafi', demi menghormati dan melindungi hak pemilik lama (Az-Zuhaili, 2011).

Bagaimanapun prinsip-prinsip dalam hukum Islam harus terpenuhi agar masyarakat menjadi sejahtera. Prinsip-prinsip tersebut seperti meniadakan kesulitan dan tidak memberatkan, menyedikitkan beban, ditetapkan secara bertahap, memperhatikan kemashlahatan manusia serta mewujudkan keadilan yang merata (Djamil, 2013). Tidak hanya itu, dalam menerapkan hukum, terdapat kaidah-kaidah yang harus diperhatikan seperti mewujudkan keadilan, mendatangkan kesejahteraan dan kemakmuran masyarakat, menerapkan hukum perbolehan dalam keadaan normal dan perbolehan dalam keadaan darurat, ganjaran harus sesuai dengan perbuatan, serta tiap-tiap manusia mempertanggung jawabkan kesalahannya sendiri (Ash-Shiddieqy, 1975).

Dalam hal penetapan harga, harus dilakukan secara wajar hingga tidak merugikan pihak manapun. Para ulama menyimpulkan hukum bahwa penguasa diharamkan untuk ikut campur dalam penentuan harga, karena hal itu di asumsikan sebagai bentuk kezaliman, sedangkan manusia bebas untuk melakukan transaksi ekonomi, dan penentuan limit harga mematikan kebebasan tersebut.

Imam Syaukani berkata, "Manusia diberikan kekuasaan atas harta kekayaan mereka, sedangkan penentuan harga (oleh pemimpin) akan membelenggu mereka. Seorang pemimpin diperintahkan untuk memelihara kemashlahatan kaum muslimin. Pandangan pemimpin terhadap kemashlahatan pembeli dengan memberikan keringanan harga tidak lebih baik dari pandangannya terhadap kemashlahatan penjual dengan memberikan harga lebih besar bagi barang dagangannya (Sabiq, 2008). Kare- 
na itu, pembatasan harga yang dilakukan oleh pemerintah akan berdampak negatif. Namun, jika harga menjadi tidak sehat karena persaingan yang sengit antar penjual, pemerintah boleh melakukan intervensi harga.

Sedangkan dalam hal pelepasan lahan, penjual adalah masyarakat, dan pembeli adalah pemerintah. Terjadi kejanggalan dimana pemerintah memiliki otoritas sebagai penguasa untuk mengambil paksa dari apa yang dimiliki masyarakat terhadap kepentingan umum, dan pemerintah juga memiliki kekuasaan untuk menentukan harga ganti rugi. Sehingga jumlah ganti rugi di anggap menzalimi karena tidak sesuai dengan keinginan masyarakat.

Untuk itu, alat ukur yang saya gunakan sehingga sesuai dengan mekanisme harga dalam Islam yaitu dengan melihat:

1. Prosedur yang dilakukan

2. Pemberian kelayakan ganti rugi

3. Pengaplikasian di lapangan

Melihat prosedur yang dilakukan pemerintah sebagaimana yang tercantum di dalam Perpres No. 71 Tahun 2012 tentang Penyelenggaraan Pengadaan Tanah Bagi Pembangunan untuk Kepentingan Umum diatas sudah sangat terperinci. Dalam prakteknya, jangan sampai masih dijumpai penyelewengan, misalnya seperti sosialisasi kepada masyarakat terhadap penggusuran paksa belum tuntas dilakukan, tetapi alat-alat berat sudah sampai di kawasan perumahan masyarakat. Atau bahkan tidak mencapai mufakat dari musyawarah yang terjadi.

Alangkah baiknya, meskipun penggusuran secara paksa karena untuk kepentingan umum, tetapi masyarakat atau pemerintah tidak terzalimi. Pemberian ganti rugi bisa dilakukan dengan musyawarah antara pemilik lahan dengan pemerintah. Ganti rugi dapat berbentuk uang, rumah, tanah pengganti, saham dan bentuk lainnya yang disetujui antar pihak. Tetapi masyarakat pada umumnya memilih dalam bentuk uang, karena bisa memiliki rumah/lahan di kawasan lain, yang lebih murah sehingga kelebihan jumlah ganti rugi bisa di simpan. Ganti rugi dalam bentuk lain seperti kepemilikan saham, sering kali tidak pernah teraplikasikan dan uang ganti rugi tersebut habis untuk memenuhi kebutuhan hidup. Namun jika uang ganti rugi tersebut habis, maka itu di luar tanggungjawab pemerintah. Karena itu akan lebih baik jika ganti rugi berupa unit rumah atau lahan pengganti sehingga bentuk ganti rugi bisa terlihat dengan jelas.

Terakhir adalah pengaplikasian di lapangan, ketika bentuk ganti rugi sudah disepakati, masyarakat juga sudah mulai pindah lahan, hasil yang diterima masyarakat haruslah sesuai dengan mufakat di awal. Jangan sampai hanya segelintir orang saja yang menerima ganti rugi yang "layak". Karenanya, pemerintah harus melakukan 
pengawasan supaya tidak hanya beberapa pihak seperti para pemuka desa saja yang menerima ganti rugi sesuai yang dijanjikan. sedangkan rakyat biasa tidak mampu untuk relokasi, hanya bisa menumpang tinggal di rumah sanak keluarga atau sampai menjadi penjaga sekolah. Karena bentuk ganti rugi yang diberikan hanya cukup untuk memenuhi biaya hidup ataupun biaya pendidikan anak.

Oleh karena itu, ganti rugi yang layak sebagai representasi kemakmuran dan kesejahteraan, karena harga terhadap ganti rugi untuk kepentingan umum ini bukan untuk pemerintah semata, melainkan mutlak untuk masyarakat sendiri agar masyarakat dapat melanjutkan hidupnya setelah pelepasan paksa dilakukan dan pada saat yang sama terciptanya kota yang bersih dan rapi. Dengan begitu tidak perlu ada perselisihan antara pemerintah dan masyarakat. 


\section{PUSTAKA ACUAN}

Ash-Shiddieqy, H. (1975). Fakta Keagungan Syariat Islam (3Rd Ed.). Jakarta: Bulan Bintang.

Az-Zuhaili, W. (2011). Fiqih Islam Wa Adillatuhu. Jakarta, Gema Insani.

Azwani, R. (2016). Hasil Wawancara. Banda Aceh.

Djamil, F. (2013). Hukum Ekonomi Islam : Sejarah, Teori, Dan Konsep. Jakarta: Sinar Grafika.

Huda, N., Idris, H. R., Nasution, M. E., \& Wiliasih, R. (2008). Ekonomi Makro Islam: Pendekatan Teoretis. Jakarta: Kencana.

Karim, A. A. (2012). Sejarah Pemikiran Ekonomi Islam (3Rd Ed.). Jakarta: Rajawali Pers.

Lasut, R. F. (2013). Pelaksanaan Bentuk Ganti Rugi Atas Tanah Menurut Uu No. 2 Tahun 2012 Tentang Pengadaan Tanah Bagi Pembangunan Untuk Kepentingan Umum. Jurnal Lex Et Societatis, I(4), 118-128.

Mahalli, A. M., \& Hasbullah, A. R. (2004). Hadis-Hadis Muttafaq 'Alaih (Bagian Munakahat Dan Mu'amalat). Jakarta: Kencana.

Manan, A. (2012). Hukum Ekonomi Syariah Dalam Perspektif Kewenangan Peradilan Agama. Jakarta: Kencana.

Marlidjanto, S. D. (2010). Konsinyasi Ganti Rugi Dalam Pengadaan Tanah Untuk Kepentingan Umum (Studi Pengadaan Tanah Untuk Pembangunan Proyek Jalan Tol Semarang - Solo Di Kabupaten Semarang. Universitas Diponegoro.

Mendagri. Peraturan Menteri Dalam Negeri Nomor 15 Tahun 1975 Tentang KetentuanKetentuan Mengenai Tata Cara Pembebasan Tanah M: , (1975).

Nazhir, M. (2005). Metode Penelitian. Jakarta : Ghalia Indonesia

Negeri, P. Kasus Perdata. , (2013).

Novie, \& Sandra, A. (2012). Analisis Tingkat Akurasi Penetapan Njop Tanah Terhadap Nilai Pasar Dengan Metode. Unisbank, Semarang.

Presiden. Keputusan Presiden Republik Indonesia Nomor 55 Tahun 1993 Tentang Pengadaan Tanah Bagi Pelaksanaan Pembangunan Untuk Kepentingan Umum. , Pub. L. No. 55 Tahun 1993, Peraturan Pemerintah Republik Indonesia Nomor 36 Tahun 2005 (1993).

Presiden. Peraturan Pemerintah Republik Indonesia Nomor 46 Tahun 2000 Tentang Penetapan Besarnya Nilai Jual Kena Pajak Untuk Penghitungan Pajak Bumi Dan Bangunan. , Pub. L. No. 46 Tahun 2000 (2000).

Presiden. Peraturan Presiden Republik Indonesia Nomor 36 Tahun 2005 Tentang Pengadaan Tanah Bagi Pelaksanaan Pembangunan Untuk Kepentingan Umum Dengan Rahmat Tuhan Yang Maha Esa. , Pub. L. No. 36 Tahun 2005 (2005). 
Presiden. Undang-Undang Republik Indonesia Nomor 28 Tahun 2009 Tentang Pajak Daerah Dan Retribusi Daerah. , Pub. L. No. 28 Tahun 2009 (2009).

Sabiq, S. (2008). Fiqh Sunnah (Terjemahan \& A. Sobari, Eds.). Jakarta: Al-I'tishom.

Sangalang, A. A. (2012). Kajian Terhadap Ganti Rugi Atas Tanah Dalam Pengadaan Tanah Bagi Pembangunan Untuk Kepentingan Umum Guna Mewujudkan Kepastian Hukum, Perlindungan Hukum, Dan Keadilan Berdasarkan Peraturan Presiden Nomor 36 Tahun 2005 Dan Peraturan Presiden Nomor 65 Tahun . Atma Jaya Yogyakarta.

Sugiarrto. (2010). Problematika Hukum Dalam Pemberian Ganti Rugi Terhadap Pengadaan Tanah Bagi Pengembangan Landas Pacu Bandar Udara Ahmad Yani Semarang Tesis. Diponegoro Semarang.

Supriadi. (2012). Hukum Agraria. Jakarta: Sinar Grafika.

Tarmizi, E. (2013). Harta Haram Muamalat Kontemporer (Pp. 1-25). Pp. 1-25. Bogor: Berkat Mulia Insani.

Walikota. Qanun Kota Banda Aceh Nomor 12 Tahun 2011 Tentang Pajak Bumi Dan Bangunan Perdesaan Dan Perkotaan. , Pub. L. No. 12 Tahun 2011 (2011). 